\title{
Development of AlGaN/GaN FETs for Power Supply
}

\author{
Ryohei Baba Non-member (Sanken Electric Co., Ltd) \\ Osamu Machida Non-member (Sanken Electric Co., Ltd) \\ Nobuo Kaneko Non-member (Sanken Electric Co., Ltd) \\ Akio Iwabuchi Non-member (Sanken Electric Co., Ltd) \\ Koji Yano Member (University of Yamanashi) \\ Takashi Matsumoto Non-member (University of Yamanashi)
}

Keywords : GaN, FET, reverse conduction, normally-off

$\mathrm{AlGaN} / \mathrm{GaN}$ FET is one of attractive candidates for next generation high power devices because of high carrier mobility in 2DEG (two-dimensional electron gas) channels and high breakdown voltage due to high critical electric field. In order to apply the AlGaN/GaN FETs for power switching applications, reverse conductive operation and normally-off characteristics are required.

In this paper, $\mathrm{AlGaN} / \mathrm{GaN}$ FET with a built-in SBD which has the reverse conductive operation and the normally-off characteristics is reported for the purpose of designing AlGaN/GaN FETs for power supply. The fabricated device exhibited a stable reverse conductive operation and a threshold voltage of $+0.8 \mathrm{~V}$. In addition, low capacitance characteristics are obtained due to the reduction of mirror effect.

Fig.1 shows a schematic cross section of the fabricated AlGaN/GaN FET (RC-GaN FET). For the purpose of normally-off characteristics, a recess gate structure is formed by ICP-RIE (inductive coupled plasma-reaction ion etching) and deposition of p-type material $/ \mathrm{Ni} / \mathrm{Au}$. As a result, the threshold voltage of $+0.8 \mathrm{~V}$ is obtained. For the reverse conductive operation, anode electrode of SBD is formed between gate electrode and drain electrode. In addition, cathode electrode was common with drain electrode and anode electrode was connected to source electrod. Anode FP (field plate) is formed for the purpose of relaxation of electric field.

$\mathrm{I}-\mathrm{V}$ characteristics of RC-GaN FET and conventional AlGaN/GaN FET are shown Fig.2. Conventional AlGaN/GaN FET shows a large voltage drop depends on gate negative voltage

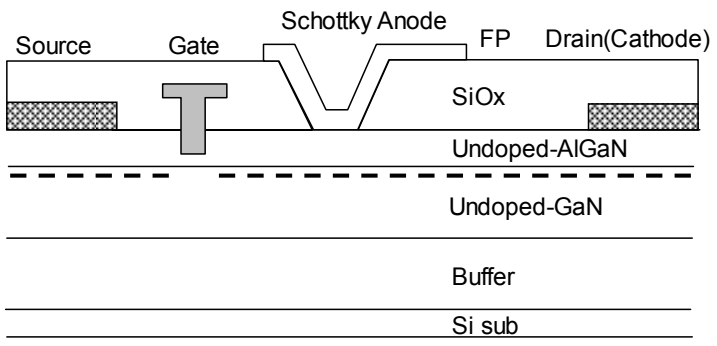

Fig. 1. Schematic cross section of the fabricated $\mathrm{AlGaN} / \mathrm{GaN}$ FET at reverse conductive state (third quadrant). On the other hand, RC-GaN FET exhibits excellent reverse conductive characteristics which do not depend on the gate negative voltage.

Capacitance characteristics of RC-GaN FET are shown Fig. 3 compared with conventional AlGaN/GaN FET. The Crss (reverse transfer capacitance) of RC-GaN FET is smaller than that of conventional $\mathrm{AlGaN} / \mathrm{GaN}$ FET due to the reduction of mirror effect. This result says that RC-GaN FET is effective for low loss power switching device.

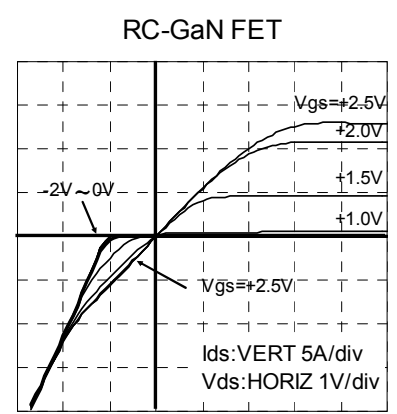

Conventional AIGaN/GaN FET

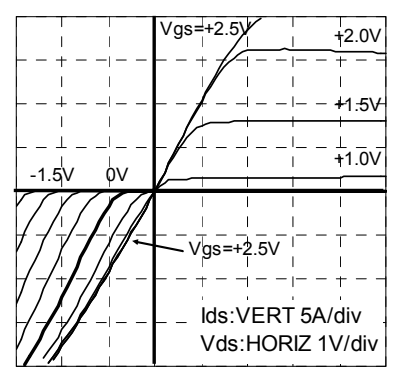

Fig. 2. I-V characteristics
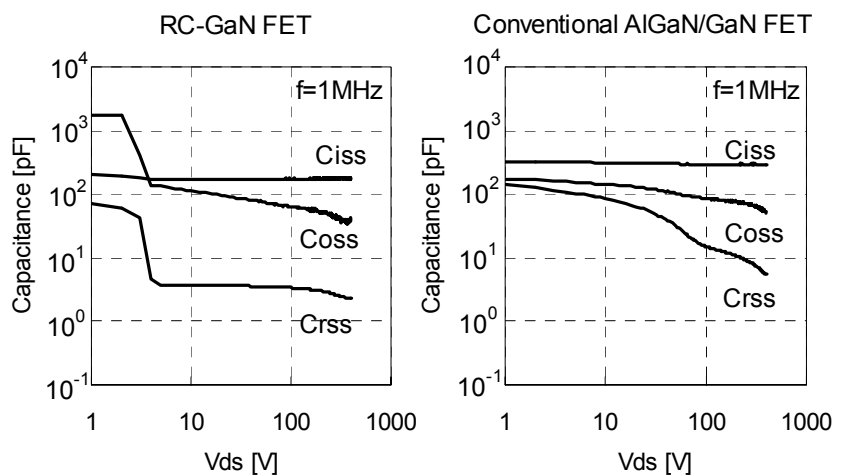

Fig. 3. Capacitance characteristics 


\section{電源用 $\mathrm{AlGaN} / \mathrm{GaN}$ FET の開発}

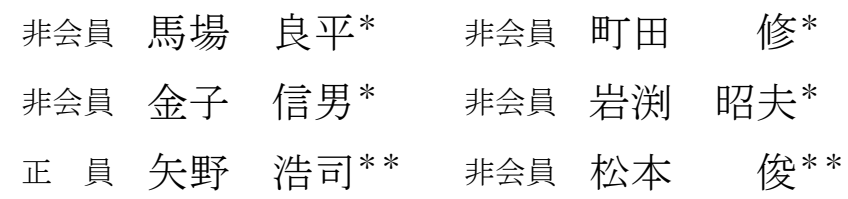

\section{Development of AlGaN/GaN FETs for Power Supply}

Ryohei Baba*, Non-member, Osamu Machida*, Non-member, Nobuo Kaneko*, Non-member, Akio Iwabuchi*, Non-member, Koji Yano**, Member, Takashi Matsumoto**, Non-member

$\mathrm{AlGaN} / \mathrm{GaN}$ FET with a built-in SBD which has a reverse conductive operation and normally-off characteristics is fabricated for the purpose of designing GaN power device for power supply. The fabricated device exhibited a threshold voltage of $+0.8 \mathrm{~V}$ and excellent reverse conductive characteristics. In addition, low capacitance characteristics are obtained due to the reduction of mirror effect. From these results, it is confirmed that the fabricated device is effective for low loss power switching device.

キーワード：窒化ガリウム，電界効果トランジスタ，逆導通，ノーマリオフ

Keywords : GaN, FET, reverse conduction, normally-off

\section{1. はじめに}

地球環境保全の観点から省エネルギー化による炭酸ガス 排出量の削減が求められている。電源機器分野においては その効率を改善することが必要であり, 機器内部で発生す る損失を低減させる回路や制御法が開発されているが，パ ワースイッチング素子そのものを低損失化することも強く 求められている。SJ（スーパージャンクション）構造を有す る Si-MOSFET や IGBT においては年々特性向上がなされて いるが，その材料物性による限界から大幅な向上は難しい。

ワイドバンドギャップ半導体である $\mathrm{GaN}$ (窒化ガリウム) は絶縁破壊電界強度が高いことから次世代のパワースイッ チングデバイスとしての期待が大きく, 多くの研究・開発 が進められている(1)。GaN 結晶の成長基板においては $\mathrm{GaN}$, サファイア， $\mathrm{SiC} ， \mathrm{Si}$ などいくつかの選択肢があるが，大口 径化，低コスト化の観点から筆者らは $\mathrm{Si}$ 基板を採用してい $ろ^{(2) \sim(4)}$

電源用途の $\mathrm{Si}$ パワーデバイスは通常, 縦型構造であるが, $\mathrm{Si}$ 基板上に $\mathrm{GaN}$ 系結晶を成長（ $\mathrm{GaN}$ on $\mathrm{Si}$ ) し縦方向に電流

* サンケン電気 (株) 技術本部 先行技術開発統括部 干352-8666 埼玉県新座市北野 3-6-3

Advanced technology development division, Sanken Electric Co., Ltd.

3-6-3, Kitano, Niiza, Saitama 352-8666

** 国立大学法人山梨大学 大学院医学工学総合研究部

干400-8510 山梨県甲府市武田 4-4-37

Interdisciplinary Graduate School of Medical and Engineering,

National university corporation, University of Yamanashi

4-4-37, Takeda, Kohu, Yamanashi 400-8510
を流した場合, $\mathrm{GaN}$ 系成長層と $\mathrm{Si}$ 基板の界面に大きな電圧 ドロップを生じるため, 縦型構造は現実的ではない。その ため横型構造を採用しているが，この場合には $\mathrm{AlGaN} / \mathrm{GaN}$ ヘテロ界面に発生する高濃度な 2 次元電子ガス（Ttwo Dimensional Electron Gas）層を導電層として利用している。 しかしながら,この導電層を利用した単純なショットキゲ 一ト構造の横型 $\mathrm{AlGaN} / \mathrm{GaN}$ FET を作製した場合, ゲート電 圧 $0 \mathrm{~V}$ においても 2 次元電子ガスがゲート電極下に存在す るため, 通常ノーマリオン特性となる。さらに, ショット キゲート構造におけるリーク電流は従来の熱電子放出理論 では説明できない大きなリーク電流特性を示し, デバイス の消費電力の増大や, 信頼性の劣化などを引き起こす。 $\mathrm{GaN}$ パワースイッチング素子の実現には上記問題を解決する事 が求められている。

電源機器よっては, スイッチング素子に電流帰還動作（逆 導通機能）を要する回路構成がある。例えば，このような 用途に逆導通機能の無い Si-IGBT を適用寸る場合, 電流帰 還用に別チップのダイオードを並列に接続した 2 チップ構 成が採用される。AlGaN/GaN FET においては通常, 安定し た逆導通特性を期待出来ないため, ダイオードを並列に接 続することが好ましい(5)。さらに低コスト化, チップ実装の 省スペース化などを考えると, FET とダイオードを 1 チッ プで構成することが望まれる。

以上のような背景, 要求を踏まえ, $\mathrm{AlGaN} / \mathrm{GaN}$ FET のリ 一ク電流抑制技術，およびノーマリオフ化技術について報 告する。またこれらの技術に加え, 電源機器への搭載を考 
えた場合に必要となる逆導通機能を有する 1 チップ $\mathrm{AlGaN} /$ GaN FET（以下，逆導通 GaN FET）について，その構造お よび特性を報告する。

\section{2. 技術要素}

〈2·1〉 リーク電流抑制技術デバイス表面側に電極 端子を設ける横型の $\mathrm{AlGaN} / \mathrm{GaN}$ FET や SBD (Schottky Barrier Diode）において高電圧が印加された場合には FET に おいてはゲート・ドレイン電極間, SBD においてはアノー ド・カソード電極間でその電圧が保持される。このとき, それぞれの電極端部に局所的に電界が集中し，そのいずれ かの電界が臨界電界に到達した時点で絶縁破壊が起こる。 そこでデバイスの耐圧を向上するため, 各電極部の電界集 中をフィールドプレート（FP）構造の適用によって緩和す る技術が用いられている(6)

金属-AlGaN 接触からなるショットキ接合のリーク電流は 従来の熱電子放出理論では説明できない大きなリーク電流 特性を示し，その原因としてトンネル効果によるリーク電 流のモデリングが提案されている(7)(8)。したがってリーク電 流を抑制するためにはFET や SBD のショットキ接合部の電 界集中を緩和することが重要と考えられる。

そこで上記背景を踏まえ, 一定傾斜を有する FP 構造によ る電界緩和機構について 2 次元デバイスシミュレーション により検証した。解析に用いたデバイス構造を Fig.1 に示す。 $\mathrm{AlGaN}$ 層は $\mathrm{Al}$ 組成 0.26 , 厚みを $25 \mathrm{~nm}$ とした。ショットキ 接合を有するゲート電極長は $2.0 \mu \mathrm{m}$, ゲート・ドレイン電極 間距離を $12 \mu \mathrm{m}$ とした。保護膜には酸化膜（SiOx）を用い, 厚みを $500 \mathrm{~nm}$ とした。ゲート電極に接続された FP 電極をド レイン電極側に配置し，SiOx により傾斜を設けた。実際の デバイス作製可能範囲を考慮した傾斜角を 2 種類設定した (Structure A， B 傾斜角 A>B)。分極電荷については $\mathrm{AlGaN} / \mathrm{GaN}$ ヘテロ界面にのみ正電荷を考慮し，ゲート電極 部においてはバリアトンネリングモデルを導入した。

各傾斜角における OFF 動作時のゲートリーク電流特性を 実際に作製したデバイスの特性も併せて Fig.2 に示寸。傾斜 角の小さい Structure B の方が，ゲートリーク電流が抑制さ れ, 実際のデバイスにおいても同様の傾向が得られた。Fig.3 にドレイン電圧 $200 \mathrm{~V}$ におけるゲート電極端部の電界分布, 及び $\mathrm{AlGaN}$ 層表面からの深さ $5 \mathrm{~nm}$ におけるチャネル方向の 電界分布を示す。Structure B の方が, 電界が緩和されている。

ショットキゲートリーク電流を抑制するために，電流経

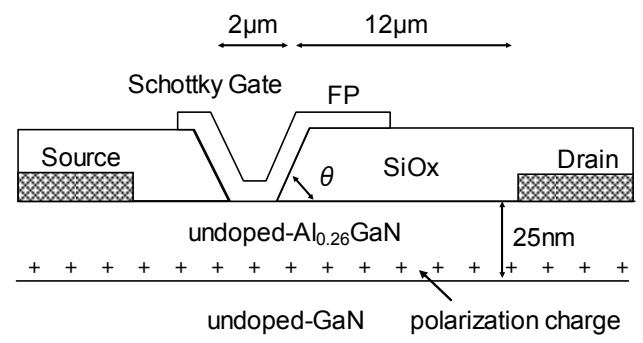

Fig. 1. Device structure for simulation
路となる電極端部の電界緩和が有効であることが，シミュ レーション，実デバイス特性の両面から確認された。SBD のアノード電極においても同様の技術によりリーク電流が 抑制できることを確認している。

〈2·2〉ノーマリオフ化技術 2 次元電子ガスを利用 した横型 $\mathrm{AlGaN} / \mathrm{GaN}$ FET において, ON 抵抗の増大を抑制 しながらノーマリオフ特性を得るためにゲートリセス構造 が用いられることが多い(9)。しかしながら通常のリセスショ ットキゲート電極構造だけでは閾值電圧は $0 \mathrm{~V}$ 付近となり 十分かつ安定したノーマリオフ特性を実現するには不十分 であると筆者らは考えている。そこで $\mathrm{GaN}$ と同等のバンド ギャップを有し, P 型の伝導性を持つ電極材料のゲート電極 構造への導入を検討した。本検討構造は通常のショットキ ゲート電極構造よりも閾值電圧を正側へシフトさせ，より 安定したノーマリオフ特性を実現できると期待される。

$\mathrm{Si}$ 基板上に成長した $\mathrm{AlGaN} / \mathrm{GaN}$ エピタキシャルウェハを

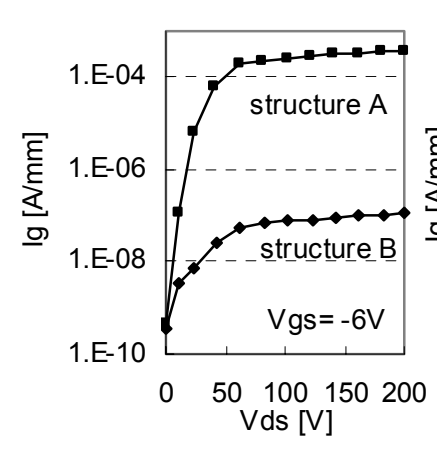

calculated result

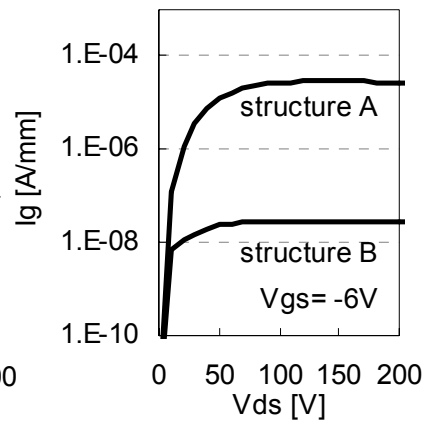

measurement result
Fig. 2. Gate leakage current characteristics

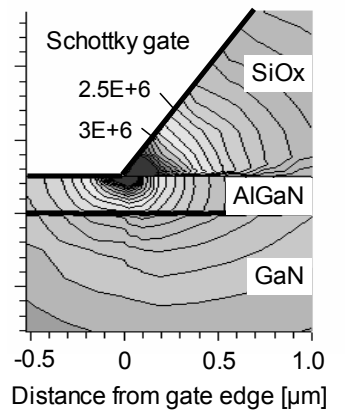

Structure A

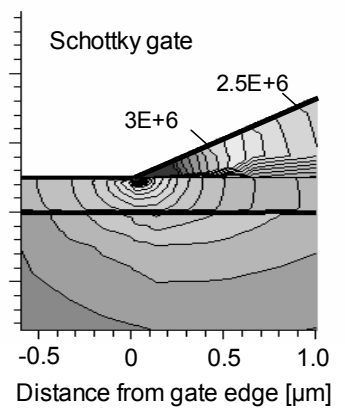

Structure B

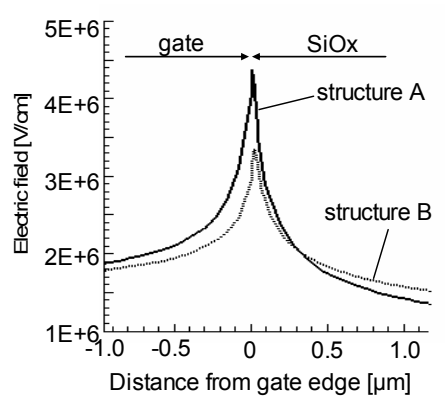

Fig. 3. Electric field distribution at gate edge 

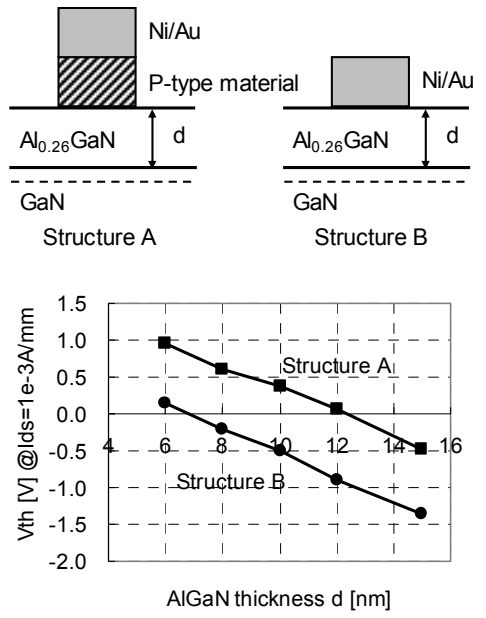

Fig. 4. Relationship between $\mathrm{AlGaN}$ thickness and Vth

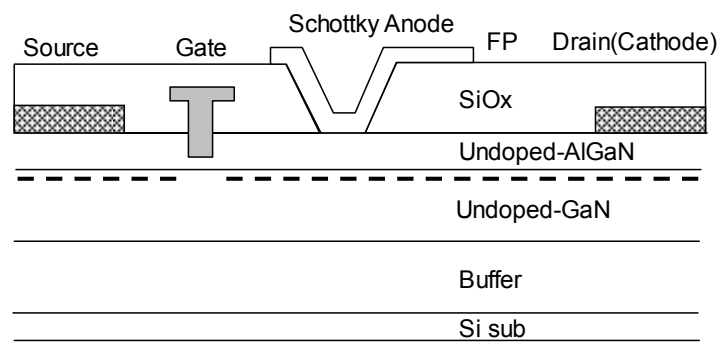

Fig. 5. Schematic cross section of reverse conduction GaN FET

用いて本検討ゲート構造（Structure A）及び比較用として $\mathrm{Ni} / \mathrm{Au}$ ショットキゲート構造（Structure B）を有するデバイ スを作製し，最上層 $\mathrm{AlGaN}$ 層厚と閾值電圧の相関を調査し た。その結果を Fig.4 に示す。Structure B に比べ, Structure A の閾值電圧は正側ヘシフトすることが確認された。その恋 化は実験水準範囲内の $\mathrm{AlGaN}$ 厚すべてに見られ，変化量は 約 $0.8 \mathrm{~V}$ であった。 $\mathrm{AlGaN}$ 層厚 $6 \mathrm{~nm}$ において闇值電圧 $1.0 \mathrm{~V}$ が得られた。

\section{3. 逆導通 GaN FET の概要}

Fig.5 に逆導通 GaN FET の断面構造を示す。使用した GaN on $\mathrm{Si}$ ウェハは $\mathrm{Si}$ 基板上にバッファ層, $\mathrm{GaN}$ 層, $\mathrm{AlGaN}$ 層を 順次積層, 約 $5 \mu \mathrm{m}$ 成長したものである。 $\mathrm{AlGaN}$ 層は $\mathrm{Al}$ 組成 が 0.26 , 厚みが $25 \mathrm{~nm}$ である。安定したノーマリオフ特性を 得るために，先述した $\mathrm{P}$ 型の伝導性を持つ電極を制御電極 に適用し，かつその直下のみ $\mathrm{AlGaN}$ 層を薄層化した。電流 帰還用ダイオードを融合するために，単純な GaN SBD の並 列接続は採用せず，ゲート電極とドレイン電極の間にショ ットキ接合されたアノード電極を配置した構造を採用し た。アノード電極はソース電極と電気的に接続し，カソー ド電極はドレイン電極と共通化した。アノード電極の設置 により OFF 動作時においてはアノード・ドレイン電極間に 強電界がかかるため, 先述した電界緩和技術をアノード電

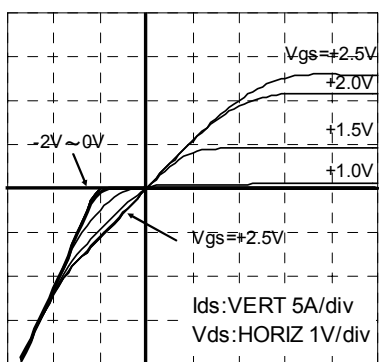

Reverse conduction GaN FET

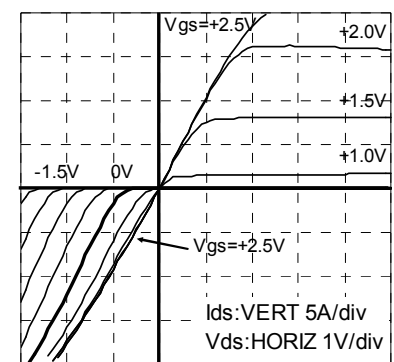

Conventional GaN FET
Fig. 6. Comparison of measured IV characteristics

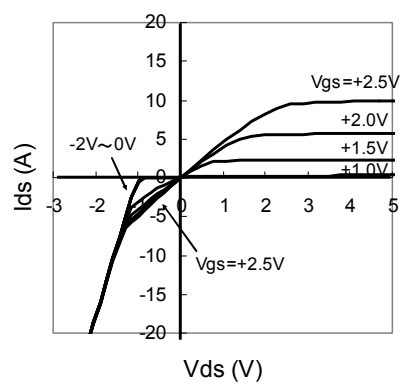

Reverse conduction GaNFET

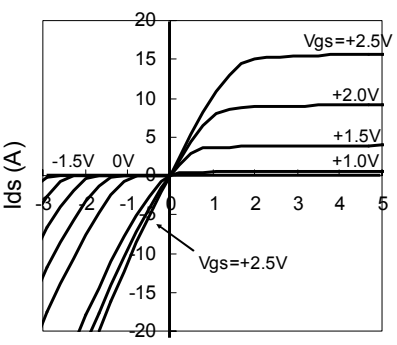

$\mathrm{Vds}(\mathrm{V})$

Conventional GaNFET
Fig. 7. Comparison of calculated IV characteristics

極部に適用した。 $600 \mathrm{~V}$ 以上の素子耐圧を得るためにアノー ド・ドレイン電極間距離は $12 \mu \mathrm{m}$ とした。特性評価の際には $\mathrm{Si}$ 基板をソース電極とショートした。

\section{4. 逆導通 GaNFET の特性}

〈4・1〉 DC 特性 Fig.6に逆導通 GaN FET, 及び比較 としてアノード電極を有さない通常のノーマリオフ型 $\mathrm{AlGaN} / \mathrm{GaN}$ FET (以下, 通常型 GaN FET) の DC 特性を示 す。測定した素子のチップサイズは $1.8 \mathrm{~mm} \times 4.2 \mathrm{~mm}^{2}$ であり， ゲート幅はそれぞれ，104mm，162mm である。通常型 $\mathrm{GaN}$ FET においてゲート電圧が負電圧の時に逆導通状態（第 3 象限）の電圧降下が大きくなる。一方, 逆導通 GaN FET に おいてはゲート電圧に依存しない良好な逆導通動作が確認 された。しかしながら飽和電流が少なく，オン抵抗が高い。 これはゲート電極幅が狭いだけでなく, アノード電極を設 置したことによりドレイン・ソース間距離が長く, ドリフ 卜部以外の寄生抵抗成分が多くなるためである。

どちらの FET も先述したゲート構造によりノーマリオフ 動作を実現し, 閾值電圧は約 $0.8 \mathrm{~V}$ であった。また破壊電圧 は $800 \mathrm{~V}$ 以上であった。

Fig.7 に 2 次元デバイスシミュレーションにより算出した DC 特性結果を示す。実デバイスの測定結果と同様, 逆導通 状態（第 3 象限）にてゲート電圧に依存しない良好な逆導 通動作が確認された。

$\langle 4 \cdot 2\rangle$ 静電容量特性 逆導通 GaN FET 及び通常型 GaN FET の静電容量 (入力容量 : Ciss, 出力容量 : Coss, 帰 還容量 : Crss）の電圧依存性を測定した。その結果を Fig.8 


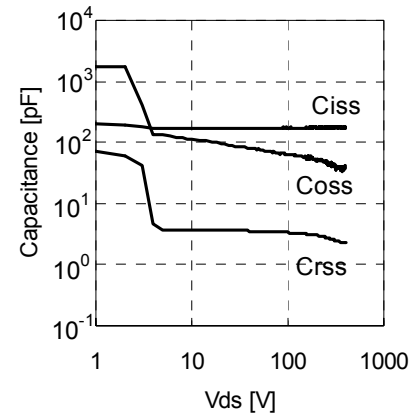

Reverse conduction GaNFET

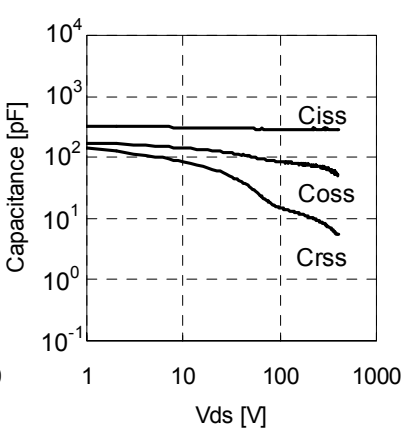

Conventional GaNFET
Fig. 8. Comparison of measured capacitance characteristics

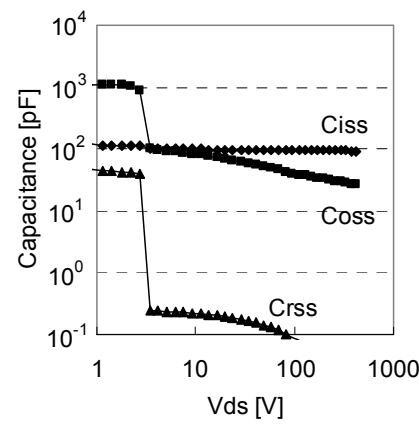

Reverse conduction GaN FET

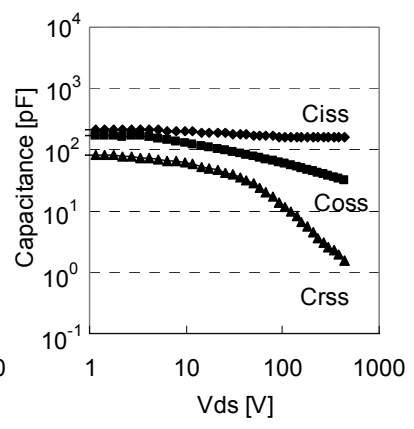

Conventional GaN FET
Fig. 9. Comparison of calculated capacitance characteristics

に示す。また 2 次元デバイスシミュレーションにより算出 した結果を Fig.9 に示す。逆導通 GaN FET の出力容量 Coss および帰還容量 : Crss が低電圧領域で大きく変化する様子 が測定值，シミュレーションによる計算值で良く一致して いる。出力容量 Coss の低電圧側での増大は，アノード電極 と電極直下の 2 次元電子ガス層が平行平板コンデンサのよ うに振舞うことで現れる特性である。すなわち容量が大き く変化する電圧 $(\mathrm{Vds} \fallingdotseq 4 \mathrm{~V})$ はアノード電極直下の 2 次元電 子ガス層が空乏化する電圧である。

逆導通 GaN FET の帰還容量 Crss は通常型 GaN FET と比 べ, 高電圧領域で極めて小さい值を示した。この理由につ いては後述する。

〈4·3〉 ゲートチャージ特性通常ゲートチャージ特 性の評価は MOSFET などの絶縁ゲートに一定電流を流し, ゲート・ソース間の充電の様子を観測する。しかしながら 逆導通 GaN FET のゲート・ソース間 Igs-Vgs 特性は立ち上 がり電圧が約 $+2.5 \mathrm{~V}$ のダイオード特性を示す(5)。そこで, 特性評価する際の測定条件としてゲートへの一定電流を $10 \mathrm{~mA}, \mathrm{Vgs}$ を $2 \mathrm{~V}$ 以下とした。この条件下ではゲート・ソ 一ス間の充電が優勢であると考えられる。また，才フ時の ドレイン電圧は $300 \mathrm{~V}$ ，オン時のドレイン電流は $6 \mathrm{~A}$ に設定 した。

Fig.10に逆導通 GaN FET のゲートチャージ特性を示す。 ゲート電圧が閾值電圧に到達し, ドレイン電流 Ids が流れ始 めるまで（off state）の電荷量 Qgs が約 $0.2 \mathrm{nC}$ と極めて小さ い。これは逆導通 GaN FET の閾值電圧が約 $0.8 \mathrm{~V}$ でありゲー

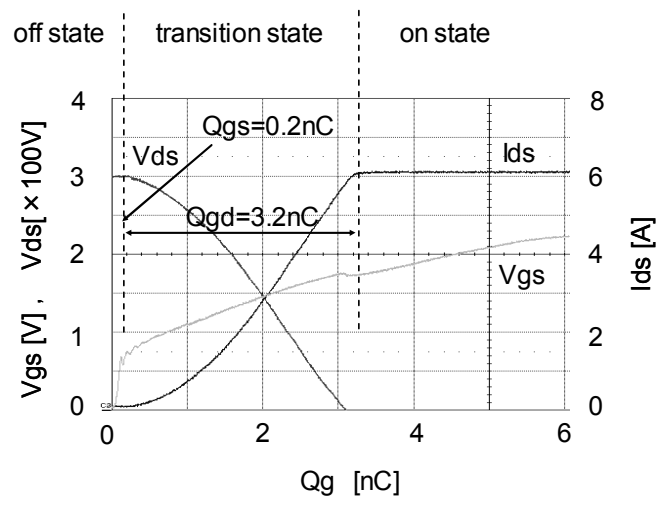

Fig. 10. Gate charge characteristics

Table 1. Comparison of Ron,Qgd,Qgs and Ron $\times$ Qgd

\begin{tabular}{|c|c|c|c|c|}
\hline & $\begin{array}{c}\text { Qgs } \\
{[\mathrm{nC}]}\end{array}$ & $\begin{array}{c}\text { Qgd } \\
{[\mathrm{nC}]}\end{array}$ & $\begin{array}{c}\text { Ron } \\
{[\Omega]}\end{array}$ & $\begin{array}{c}\text { Ron } \times \text { Qgd } \\
{[\Omega \cdot \mathrm{nC}]}\end{array}$ \\
\hline Conventional GaN FET & 0.2 & 9.0 & 0.09 & 0.81 \\
\hline Reverse conduction GaN FET & 0.2 & 3.2 & 0.18 & 0.58 \\
\hline Si SJ MOSFET & 2.0 & 11.0 & 0.68 & 7.50 \\
\hline
\end{tabular}

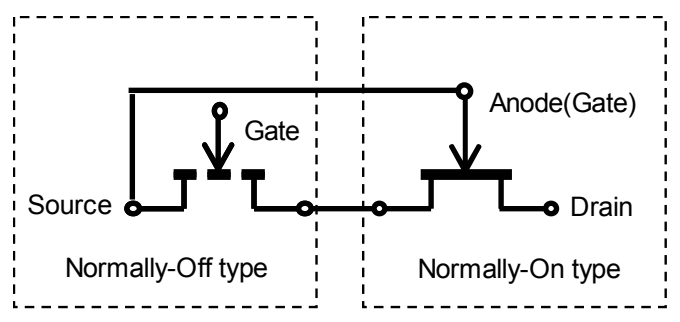

Fig. 11. Equivalent circuit of reverse conduction GaN FET

ト・ソース間容量 $\mathrm{Cgs}$ が小さいことによる。さらにゲート 電荷量を増すと FET はターンオンし，ミラー効果のため等 価入力容量が増大寸る。入力容量増大によりゲート電压 Vgs の増加傾向が抑制される期間, 寸なわち FET がオフ状態か ら完全なオン状態に移行するまで（transition state）の電荷量 Qgd は 3.2nCであった。

パワーデバイスの損失に対する性能指標であるオン抵抗 とゲート・ドレイン間電荷量の積, Ron $\times$ Qgd を通常型 GaN FET 及び SJ 型 Si-MOSFET（定格電圧 $600 \mathrm{~V}$ ）の結果も併せ て Table 1 に示す。逆導通 GaN FET はオン抵抗が高いものの, Qgd が低いため性能指数は 0.58 と低い值となり, MOSFET と比べると約 $1 / 10$ 以下の值となった。これは逆導通 $\mathrm{GaN}$ FET がパワースイッチング素子として優れていることを示 す結果である。

Fig.11 に逆導通 GaN FET の等価回路を示す。ゲート・ア ノード間で分割すると, ソース接地されたノーマリオフ型 FET とゲート接地されたノーマリオン型 FET のカスコード 接続(10)(11) と等価な構成となっている。そのためアノード・ ドレイン電極間容量電荷の充放電がゲート電極を介さない ことからゲート・ソース電極間容量が等価的に増大するミ 
ラー効果を抑制できる。逆導通 GaN FET の Qgd が少ないの はこのためであり, 帰還容量 Crss が小さいことも同様の理 由によるものである。

\section{5. おわりに}

電源機器への搭載を想定した $\mathrm{AlGaN} / \mathrm{GaN}$ FET において必 要とされるノーマリオフ動作，リーク電流抑制技術を紹介 した。これらの技術を取り入れた逆導通機能を有する 1 チ ップ GaN FET を試作し特性を評価した結果, 良好な FET 動 作と逆導通動作が同時に得られる事を確認した。また, 試 作したデバイスはミラー効果が抑制され，パワースイッチ ング素子として優れた特性を示すことを確認した。電源へ 搭載した際の省エネルギー効果が期待できる。また，今回 2 次元デバイスシミュレーションによる計算值が，測定值の 傾向を精度良く再現できることも確認出来た。シミュレー ションの利用により効率的な開発が期待できる。

(平成 21 年 9 月 24 日受付, 平成 22 年 2 月 16 日再受付)

\section{文献}

（1）吉田清輝：「GaN を用いた電子デバイス」, 応用物理, Vol.68, No.7, pp.787-792 (1998-7)

(2) S. Iwakami, M. Yanagihara, O. Machida, E. Chino, N. Kaneko, H. Goto, and K. Ohtsuka : "AlGaN/GaN Heterostructure Field-Effect Transistors (HFETs) on Si Substrates for Large-Current Operation", Jpn. J. Appl. Phys., Vol.43, No.7, pp.L831-L833 (2004)

(3) S. Iwakami, O. Machida, Y. Izawa, R. baba, M. Yanagihara, T. Ehara, N. Kaneko, H. Goto, and A. Iwabuchi : "Evaluation of AlGaN/GaN Heterostructure Field-Effect Transistors on Si Substrate in Power Factor Correction Circuit", Jpn. J. Appl. Phys., Vol.46, No.29, pp.L721-L723 (2007)

（4）大塚康二:「 $\mathrm{Si}$ 基板上への窒化物半導体のエピタキシャル成長技術と インパクト」, 応用物理, Vol.76, No.5, pp.489-494 (2007)

（5）金子信男・町田 修:「ノーマリオフ型 GaN FET の開発」, サンケン 技報, Vol.40, pp.19-22 (2008-12)

（6）酒井亮輔・西田猛利・塩島謙次・暮原正明：「多段及び傾斜フィール ドプレートを有する AlGaN/GaNHEMT の理論検討」，信学技報， Vol.107, No251, pp.47-52 (2007-10)

（7）小谷淳二・金子昌充・橋詰 保 : 「Al 薄膜を用いた表面プロセスに よる AlGaN ショットキー界面のリーク電流制御」, 信学技報, Vol.106, No.47, pp.91-94 (2006-5)

(8) S. Karmalkar, N. Satyan, and D. M. Sathaiya : "On the Resolution of the Mechanism for Reverse Gate Leakage in AlGaN/GaN HEMTs", IEEE Electron Device Letters, Vol.27, No.2, pp.87-89 (2006-2)

(9) W. Saito, Y. Takada, M. Kuraguchi, K. Tsuda, and I. Omura "Recessed-Gate Structure Approach Toward Normally Off High-Voltage AlGaN/GaN HEMT for Power Electronics Applications", IEEE Trans. Electron Devices, Vol.53, No.2, pp.356-362 (2006-2)

(10) S. Iwakami, O. Machida, Y. Izawa, R. Baba, M. Yanagihara, T. Ehara, N. Kaneko, H. Goto, and A. Iwabuchi : "Evaluation of AlGaN/GaN Heterostructure Field-Effect Transistors on Si Substrate in Power Factor Correction Circuit", Jpn. J. Appl. Phys., Vol.46, No.24, pp.L721-L723 (2007)

(11) 猪澤道能・町田 修:「高耐圧 $\mathrm{GaN}$ デバイスのスイッチング電源へ の搭載」，サンケン技報, Vol.39, pp.43-46 (2007-12)

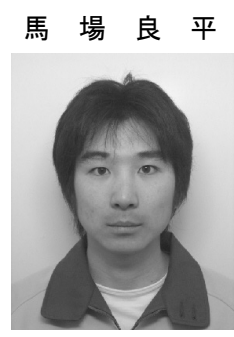

（非会員） 1978 年 5 月生。 2002 年 3 月，東京 理科大学大学院材料工学科修士課程修了。同年 4 月, サンケン電気（株）入社。主として窒化 ガリウム系電子デバイスの開発に従事。

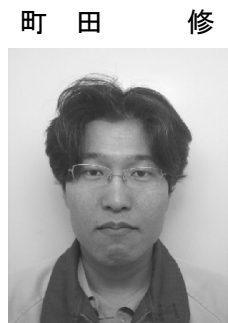

（非会員） 1968 年 7 月生。1993 年 3 月, 長岡 技術科学大学院電子機器工学専攻修了。同年业 ンケン電気 (株) 入社。主として化合物半導体 高周波増幅器の開発をへて, GaN on Si 電子デ バイスの研究開発に従事。

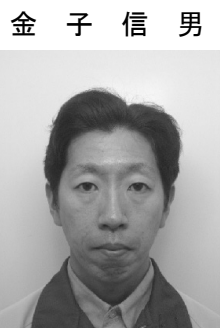

（非会員） 1969 年 3 月生。1994 年 3 月，九州 大学大学院総合理工学研究科修士課程修了。同 年サンケン電気 (株) 入社。主として高周波増 幅器，高周波・高耐圧デバイスの開発をへて, $\mathrm{GaN}$ on $\mathrm{Si}$ 電子デバイスの開発に従事。

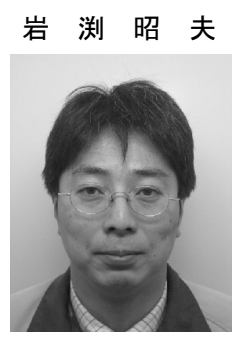

（非会員） 1958 年生。1982 年 3 月, 東京電機 大学応用理化学科卒業。同年サンケン電気 (株) 入社。主としてディスクリートデバイス及びパ ワーIC プロセスデバイスの開発に従事。現在, 先行技術開発統括部長。

矢 野 浩 司

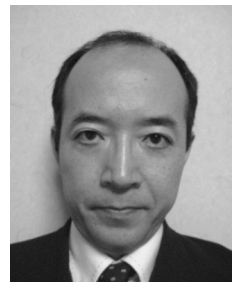

松 本 俊

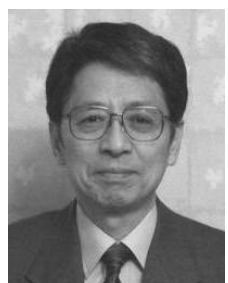

（正員） 1964 年 7 月生。1988 年 3 月, 静岡大 学電子工学科卒業。93 年 3 月同大学博士課程 修了。同年山梨大学工学部助手。1999 年～2000 年カナダ・トロント大学客員研究員。2006 年 より助教授を経て現在准教授。Si および化合物 半導体電力用半導体素子の設計およびプロセ スに関する研究に従事。工学博士。

（非会員） 1946 年 11 月生。1969 年 3 月, 東京 大学電子工学科卒業, 74 年 3 月同電子工学専攻 博士課程修了。同年山梨大学電子工学科講師, 助教授を経て現在教授。化合物半導体の結晶成 長と電子光物性の研究に従事。元応用物理学会 理事, 分科会・研究会幹事長。工学博士。 